\title{
Human Eosinophils Have Prolonged Survival, Enhanced Functional Properties, and Become Hypodense When Exposed to Human Interleukin 3
}

\author{
Marc E. Rothenberg, William F. Owen, Jr., David S. Silberstein, Jan Woods, Roy J. Soberman, \\ K. Frank Austen, and Richard L. Stevens \\ Department of Medicine, Harvard Medical School, Boston, Massachusetts 02115; and the Department of Rheumatology and \\ Immunology, Brigham and Women's Hospital, Boston, Massachusetts 02115
}

\begin{abstract}
Human eosinophils were cultured in the presence of recombinant human IL-3 for up to $14 \mathrm{~d}$ and their biochemical, functional, and density properties were assessed. After $3 \mathrm{~d}$ of culture in 10 pM IL-3, eosinophils had a viability of $70 \%$ compared with only $10 \%$ in enriched medium alone. Neither IL-1 $\mathbf{1}_{\alpha}$, IL-2, IL-4, tumor necrosis factor, basic fibroblast growth factor, nor platelet-derived growth factor maintained eosinophil viability. The 7- and 14-d survival of the cultured eosinophils was 55 and 53\%, respectively. No other cell type, including neutrophils, was present after culture. After $7 \mathrm{~d}$ of culture, the normodense eosinophils were converted to hypodense cells as assessed by density centrifugation. Eosinophils exposed to 1,000 pM IL-3 for 30 min or cultured in 10 pM IL-3 for 7 d generated approximately threefold more leukotriene $C_{4}$ (LTC $)_{4}$ in response to calcium ionophore than freshly isolated cells. Furthermore, whereas freshly isolated eosinophils killed only $14 \%$ of the antibody-coated Schistosoma mansoni larvae, these eosinophils killed $54 \%$ of the larvae when exposed to 100 pM IL-3. The enhanced helminth cytotoxicity was maintained for $7 \mathrm{~d}$ when eosinophils were cultured in the presence of both 10 pM IL-3 and 3T3 fibroblasts, but not when eosinophils were cultured in the presence of IL-3 alone. IL-3 thus maintains the viability of eosinophils in vitro, augments the calcium ionophore-induced generation of $\mathrm{LTC}_{4}$, enhances cytotoxicity against antibody-sensitized helminths, and induces the eosinophils to become hypodense cells. These phenotypic changes in the eosinophil may be advantageous to host defense against helminthic infections but may be disadvantageous in conditions such as allergic disease.
\end{abstract}

\section{Introduction}

The viability of human peripheral blood eosinophils can be maintained in vitro for at least $14 \mathrm{~d}$ when these cells are cocultured in the presence of either human or bovine endothelial cells (1) or a combination of human recombinant granulocyte/macrophage-colony-stimulating factor (GM-CSF) ${ }^{1}$ and

Address reprint requests to Marc Rothenberg, Harvard Medical School, The Seeley G. Mudd Bldg., Room 618, 250 Longwood Avenue, Boston, MA 02115.

Received for publication 20 October 1987 and in revised form 5 January 1988.

1. Abbreviations used in this paper: GM-CSF, granulocyte/macrophage colony-stimulating factor; $\mathrm{LTC}_{4}$, leukotriene $\mathrm{C}_{4}$.

J. Clin. Invest.

(c) The American Society for Clinical Investigation, Inc.

0021-9738/88/06/1986/07 $\$ 2.00$

Volume 81, June 1988, 1986-1992 mouse $3 \mathrm{~T} 3$ fibroblasts (2). As compared with replicate freshly isolated normodense eosinophils, the cultured eosinophils increase their capacity to generate leukotriene $\mathrm{C}_{4}\left(\mathrm{LTC}_{4}\right)$ in response to calcium ionophore, increase their cytotoxicity against antibody-coated Schistosoma mansoni larvae and are converted to hypodense cells as assessed by sedimentation analysis. Hypodense eosinophils, defined by their lower than normal sedimentation density in discontinuous metrizamide or Percoll gradients, have been found in the peripheral blood of some patients with eosinophilia-associated diseases such as the idiopathic hypereosinophilic syndrome and chronic infection with $S$. mansoni (3-6). These eosinophils generate more $\mathrm{LTC}_{4}$ in response to activation with calcium ionophore (7) and kill more antibody-coated $S$. mansoni larvae (5) than normodense eosinophils.

IL-3 and GM-CSF stimulate bone marrow progenitors in vitro to form colonies of cells that include eosinophils (8-10). However, IL-3 is distinct from GM-CSF because it induces bone marrow progenitors to form colonies that are more diverse in cell type. In addition, murine IL-3 preferentially stimulates the growth and differentiation of mast cells in culture (11). Gibbon recombinant IL-3 augments the functional properties of mature human peripheral blood eosinophils by acutely increasing their generation of superoxide, their phagocytosis of opsonized yeast, and their antibody-dependent killing of tumor cells (10).

In the present investigation, we report that human peripheral blood normodense eosinophils cultured with human recombinant IL-3 survive for at least $14 \mathrm{~d}$ and are converted to hypodense cells. Both acute and chronic exposure to IL-3 results in enhanced calcium ionophore-induced generation of LTC $_{4}$. Acute treatment with IL-3 also increases eosinophil cytotoxicity against antibody-coated $S$. mansoni larvae; however, preserving this enhanced cytotoxic activity requires coculture of eosinophils in the presence of both IL-3 and 3T3 fibroblasts. These studies indicate that IL-3 and GM-CSF promote proinflammatory changes in eosinophils characterized by prolonged viability, enhanced functional properties, and hypodensity.

\section{Methods}

Isolation of human eosinophils. Human eosinophils were isolated by centrifugation in discontinuous metrizamide gradients $(12,13)$ from the peripheral blood of nine different donors, none of whom were ingesting corticosteroids, aspirin, or nonsteroidal antiinflammatory drugs. Two of these donors had no diagnosed clinical disorder and had normal white blood counts and differentials. The other seven donors were diagnosed as having allergic rhinitis, allergic conjunctivitis, and/ or asthma; $2-10 \%$ of their white blood cells were eosinophils. Whole blood (45-ml aliquots) was aspirated into $60-\mathrm{ml}$ syringes, each containing 1,000 U of sterile heparin (Sigma Chemical Co., St. Louis, 
MO). All subsequent steps were performed under sterile conditions in a laminar flow hood using reagents that were filtered through $0.45-\mu \mathrm{m}$ filters. To each syringe was added $9 \mathrm{ml}$ of prewarmed PBS containing 4.5\% (wt/vol) of 150,000-200,000 $M_{\mathrm{r}}$ dextran (BDH Chemicals, Poole, England), $\mathrm{pH}$ 7.3. After a $45-\mathrm{min}$ incubation at $37^{\circ} \mathrm{C}$, the buffy coats were collected. An equal volume of isolation medium (RPMI1640 supplemented with $100 \mathrm{U} / \mathrm{ml}$ of penicillin, $100 \mu \mathrm{g} / \mathrm{ml}$ of streptomycin, $10 \mu \mathrm{g} / \mathrm{ml}$ of gentamycin, $2 \mathrm{mM}$ L-glutamine, $0.1 \mathrm{mM}$ nonessential amino acids, 10\% [vol/vol] FCS, $1 \mathrm{mM}$ Hepes [Gibco Laboratories, Grand Island, NY], and $45 \mathrm{U} / \mathrm{ml}$ of deoxyribonuclease-1 [Sigma Chemical Co.], $\mathrm{pH} 7.2$ ) was added and the cells were centrifuged at 250 $g$ for $10 \mathrm{~min}$ at $4^{\circ} \mathrm{C}$. The mixed leukocyte preparations were resuspended in isolation medium at a density of $\sim 3.0 \times 10^{7}$ cells $/ \mathrm{ml}$.

Metrizamide (Nyegaard and Co., Oslo, Norway) was dissolved in Tyrode's buffer containing $0.1 \%$ (wt/vol) gelatin and $45 \mathrm{U} / \mathrm{ml}$ of deoxyribonuclease to concentrations of $18,20,21,22,23$, and $24 \%$ (wt/vol). The densities were standardized by their refractive indices $(r$ $=1.3620,1.3650,1.3665,1.3680,1.3695,1.3710$ for the $18,20,21,22$, 23 , and $24 \%$ metrizamide layers, respectively). Gradients were prepared by pipetting $2 \mathrm{ml}$ of each solution of metrizamide stepwise into $15-\mathrm{ml}$ tubes or by pipetting $7 \mathrm{ml}$ of each solution into $50-\mathrm{ml}$ tubes. After the addition of $1.5 \mathrm{ml}$ of the leukocyte suspension into each $15-\mathrm{ml}$ tube or $7 \mathrm{ml}$ into each $50-\mathrm{ml}$ tube, samples were centrifuged at $1,000 \mathrm{~g}$ for $45 \mathrm{~min}$ at room temperature. The cells recovered at the $22 / 23 \%$ and $23 / 24 \%$ gradient interfaces were pooled with those cells that pelleted to the bottom of the gradient. The purity of the starting population of metrizamide-purified normodense eosinophils was $84 \pm 10 \%$ (mean $\pm \mathrm{SD}, n=22$ ) as assessed by Wright's and Giemsa staining. Neutrophils were the principal leukocyte contaminant. Residual contaminating erythrocytes in the eosinophil preparations were eliminated by hypotonic lysis. Cell viability in all experiments was $>98 \%$ as assessed by trypan blue (Gibco Laboratories) exclusion.

Culture of human eosinophils. Freshly isolated eosinophils $\left(10^{5}\right)$ were resuspended in $180 \mu \mathrm{l}$ of enriched medium (isolation medium without Hepes and without deoxyribonuclease) in 96-well, flat-bottom microtiter plates containing $20 \mu \mathrm{l}$ of various dilutions of a specific cytokine. Cells were cultured for $3 \mathrm{~d}$ at $37^{\circ} \mathrm{C}$ in a humidified atmosphere of $5 \% \mathrm{CO}_{2}$. Human recombinant IL-3 was kindly provided by Dr. Y.-C. Yang (Genetics Institute, Cambridge, MA) and Dr. C. Sieff (Harvard Medical School, Boston, MA) as a Cos cell supernatant (14). The protein concentration of the Cos cell supernatant was $\sim 1 \mu \mathrm{g} / \mathrm{ml}$ and consisted of $\sim 90 \%$ IL-3. Purified human recombinant IL-3 that was expressed in Escherichia coli was also kindly provided by Dr. Y.-C. Yang. Purified human recombinant GM-CSF that was expressed in monkey Cos cells was kindly provided by Dr. Judith Gasson (University of California at Los Angeles, Los Angeles, CA) (15) and Dr. S. C. Clark (Genetics Institute) (16). Human recombinant IL-1 $1_{\alpha}$ (Collaborative Research, Bedford, MA), human recombinant IL-2 (Cetus Corp., Emeryville, CA), human recombinant IL-4 (Dr. D. Rennick, DNAX, Palo Alto, CA), human platelet-derived growth factor, bovine pituitary basic fibroblast growth factor (Collaborative Research), and human recombinant tumor necrosis factor (Cetus Corp.) were also used in some experiments.

For 7-14-d culture experiments, freshly isolated eosinophils were resuspended at a density of $2.5-5.0 \times 10^{5}$ cells $/ \mathrm{ml}$ in enriched medium containing $10 \mathrm{pM} \mathrm{IL-3}$ or $10 \mathrm{pM}$ GM-CSF. $2 \mathrm{ml}$ of this suspension was seeded into $35-\mathrm{mm}$ culture dishes containing or lacking a confluent monolayer of mouse 3T3 fibroblasts. Fibroblasts (line CCL 92; American Type Culture Collection, Rockville, MD) were grown in enriched medium as described previously (2). At 48-h intervals, the culture medium containing the suspension of eosinophils was aspirated, and 1 $\mathrm{ml}$ of fresh enriched medium was added directly to each culture plate. The eosinophils in each aspirate were centrifuged at $250 \mathrm{~g}$ for $10 \mathrm{~min}$ at room temperature, resuspended in $1.0 \mathrm{ml}$ of fresh enriched medium containing IL-3 or GM-CSF, and added back to the appropriate original culture dish. In some experiments, eosinophils were cultured under similar conditions except that IL-3 was either not added during the culture or was included only at the time of the initial seeding.
Analysis of the viability and density of eosinophils after culture. Eosinophils were recovered from each culture plate by washing the plate five times with $2 \mathrm{ml}$ of enriched medium and pooling the collected suspension of cells. After centrifugation at $250 \mathrm{~g}$ for $10 \mathrm{~min}$ at $4^{\circ} \mathrm{C}$, the cells were resuspended in $1 \mathrm{ml}$ of enriched medium, and $50 \mu \mathrm{l}$ was added to an equal volume of trypan blue. Those eosinophils that excluded trypan blue after a 5 -min incubation at $37^{\circ} \mathrm{C}$ were considered viable cells. The number and percent of eosinophilic cells in the preparations were determined by counting the total cells with a hemacytometer and staining replicate samples of cytocentrifuge preparations with Wright's and Giemsa stains. The survival of the cultured eosinophils was calculated as follows: $100 \times$ total number of eosinophils remaining $X$ percent of cells excluding trypan blue/original number of eosinophils seeded. Color photomicrographs of eosinophils were taken through a Nikon Labaphore CFN microscope utilizing a Hitashi KPC-100 color video camera and printer (courtesy of the Monsanto Corp., Natick, MA). To assess the relative density of the eosinophils after culture, $0.5-2.0 \times 10^{6}$ cells were suspended in $1.5 \mathrm{ml}$ of enriched medium and centrifuged over discontinuous gradients of metrizamide as described above. The eosinophils at each metrizamide interface were collected, diluted with $\sim 10 \mathrm{ml}$ of enriched medium, sedimented at $250 \mathrm{~g}$ for $10 \mathrm{~min}$ at $4^{\circ} \mathrm{C}$, resuspended in $1 \mathrm{ml}$ of enriched medium, and counted. Viability and morphology were assessed as described above.

Calcium ionophore-induced generation of $L T C_{4}$. Replicate samples of freshly isolated and cultured eosinophils were each resuspended in $3 \mathrm{ml}$ of modified Tyrode's buffer, $\mathrm{pH} 7.5$, containing $0.3 \mathrm{mM} \mathrm{KCl}, 1$ $\mathrm{mM} \mathrm{CaCl}_{2}, 5 \mathrm{mM} \mathrm{MgCl}, 0.1 \%$ (wt/vol) gelatin, and $20 \mathrm{mM} \mathrm{L}$-serine. The latter amino acid was added to prevent $\mathrm{HOCl}$-dependent oxidative metabolism of $\mathrm{LTC}_{4}$ (13). After two successive washes with modified Tyrode's buffer at $110 \mathrm{~g}$ for $10 \mathrm{~min}$ at $4^{\circ} \mathrm{C}$, the replicate eosinophils were pooled and resuspended in the same buffer at a density of $2 \times 10^{6}$ cells $/ \mathrm{ml}$. Samples $(100 \mu \mathrm{l})$ of each cell suspension were prewarmed for $10 \mathrm{~min}$ at $37^{\circ} \mathrm{C}$ in a humidified atmosphere of $5 \% \mathrm{CO}_{2}$. The eosinophils that had been freshly isolated were then incubated with $100 \mu$ l of modified Tyrode's buffer lacking or containing IL-3 (0.04 to $4,000 \mathrm{pM})$ for $30 \mathrm{~min}$ at $37^{\circ} \mathrm{C}$. As a positive control, eosinophils were also exposed to $20 \mathrm{pM}$ GM-CSF for the same preincubation interval before the addition of the calcium ionophore. The cultured eosinophils were washed twice with modified Tyrode's buffer, and then samples $(100 \mu \mathrm{l})$ of eosinophils at $2 \times 10^{6}$ cells $/ \mathrm{ml}$ were prewarmed for $10 \mathrm{~min}$ at $37^{\circ} \mathrm{C}$ in a humidified atmosphere of $5 \% \mathrm{CO}_{2}$. Calcium ionophore $\mathrm{A} 23187$ in $100 \mu \mathrm{l}$ of buffer (final concentration $2.5-\mu \mathrm{M}$ ) (13) was added for $30 \mathrm{~min}$ at $37^{\circ} \mathrm{C}$ and the activation was terminated by adding $2 \mathrm{ml}$ of methanol at $4^{\circ} \mathrm{C}$. Each methanolic suspension was placed under argon at $4^{\circ} \mathrm{C}$ for $\sim 14 \mathrm{~h}$ and then centrifuged at $500 \mathrm{~g}$ for $30 \mathrm{~min}$ at $4^{\circ} \mathrm{C}$ to remove proteins and cell debris. The methanolic extract was stored at $-20^{\circ} \mathrm{C}$ under argon.

Immunoreactive $\mathrm{LTC}_{4}$ was quantitated by RIA of the methanolic extracts of each reaction mixture. The methanolic extracts were evaporated to dryness under negative pressure (Speed Vac Concentrator; Savant Instruments, Hicksville, NY), and resuspended in Tris-Isogel buffer $(0.1 \mathrm{M}$ Tris- $\mathrm{HCl}, 0.14 \mathrm{M} \mathrm{NaCl}$, and $0.1 \%$ gelatin, $\mathrm{pH} 7.4)$. Samples $(100 \mu \mathrm{l})$ were each mixed with $50 \mu \mathrm{l}$ of ${ }^{3} \mathrm{H}$-labeled $\mathrm{LTC}_{4}(40$ $\mathrm{Ci} / \mathrm{mmol}$; New England Nuclear, Boston, MA), and $100 \mu \mathrm{l}$ of immune rabbit plasma as described $(13,17)$. Unbound ${ }^{3} \mathrm{H}$-labeled $\mathrm{LTC}_{4}$ was removed by incubating samples for $15 \mathrm{~min}$ at $4^{\circ} \mathrm{C}$ with $1 \mathrm{ml}$ of a $10: 1$ (wt/wt) suspension of charcoal/dextran T-40 (Sigma Chemical Co.) in Tris-Isogel buffer (2). The charcoal was removed by centrifugation at $2,000 \mathrm{~g}$ for $15 \mathrm{~min}$ at $4^{\circ} \mathrm{C}$; the residual radioactivity in the supernatant was quantified by $\beta$-scintillation counting. In this RIA, synthetic LTC $_{4}$ was detectable on the linear portion of the radioligand inhibition-binding curve at concentrations ranging from 0.1 to $1.0 \mathrm{ng}$. Statistical analysis was determined by the two-tailed $t$ test.

Cytotoxicity assay. Freshly isolated and cultured eosinophils were washed two times with $15 \mathrm{ml}$ of Eagles's modified essential medium containing $100 \mathrm{U} / \mathrm{ml}$ of penicillin, $100 \mu \mathrm{g} / \mathrm{ml}$ of streptomycin, $2 \mathrm{mM}$ L-glutamine, $1 \mathrm{mM}$ Hepes, and $10 \%$ heat-inactivated $\left(56^{\circ} \mathrm{C}, 30 \mathrm{~min}\right)$ 


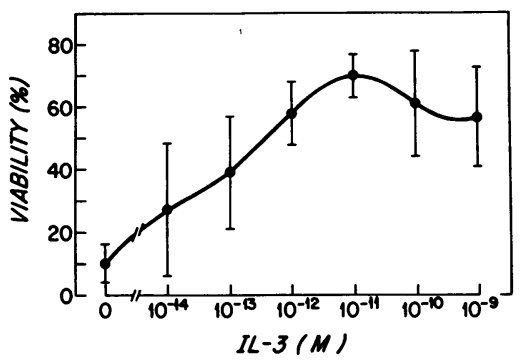

fetal bovine serum (enriched MEM). Cells were resuspended at a density of $2 \times 10^{6}$ cells $/ \mathrm{ml}$ in enriched MEM, and 50- $\mu 1$ samples were added to individual wells of a 96-well, round-bottomed microtiter plate. $50 \mu 1$ of enriched MEM lacking cytokine, or containing either GM-CSF (40 pM) or IL-3 (0.04 to $4,000 \mathrm{pM})$ was added, and the eosinophils were incubated for $15 \mathrm{~min}$ at $37^{\circ} \mathrm{C}$ in a sealed, humidified box. A 50- $\mu$ l portion of enriched MEM containing pooled, heat-inactivated sera (1:50 final dilution) from patients with $S$. mansoni infections, along with $50 \mu \mathrm{l}$ of mechanically transformed $S$. mansoni larvae $\left(2 \times 10^{3} \mathrm{worms} / \mathrm{ml}\right)$ were added to each well $(18)$. The viability of the larvae was assessed $24 \mathrm{~h}$ later by microscopy using motility, contractility, and toluidine blue exclusion as criteria (19). In some wells, eosinophils were omitted to ensure that none of the reagents directly influenced the viability of the schistosomula.

\section{Results}

IL-3 enhancement of eosinophil viability. As assessed by their uptake of trypan blue, only $10 \pm 6 \%$ (mean $\pm \mathrm{SD}, n=10$ ) of the starting population of human eosinophils were viable after $3 \mathrm{~d}$ of culture in enriched medium alone (Fig. 1). In contrast, replicate samples of eosinophils cultured in enriched medium supplemented with incremental concentrations of IL-3 showed a dose-dependent enhanced viability at $3 \mathrm{~d}$. A maximum viability of $70 \pm 7 \%($ mean \pm SD, $n=10)$ was obtained at a $10 \mathrm{pM}$ concentration of IL-3 (Fig. 1), while the concentration of IL-3 that resulted in a $50 \%$ maximal viability was $0.1 \mathrm{pM}$. Using purified IL-3, eosinophils from two different donors had a maximal 3-d viability of 80 and $78 \%$ at 10 and 100 pM IL-3, respectively. When eosinophils were cultured for $7 \mathrm{~d}(n=8)$ and $14 \mathrm{~d}(n=3)$ in the presence of $10 \mathrm{pM}$ IL-3 under conditions in which the medium was replaced every $48 \mathrm{~h}$ with fresh

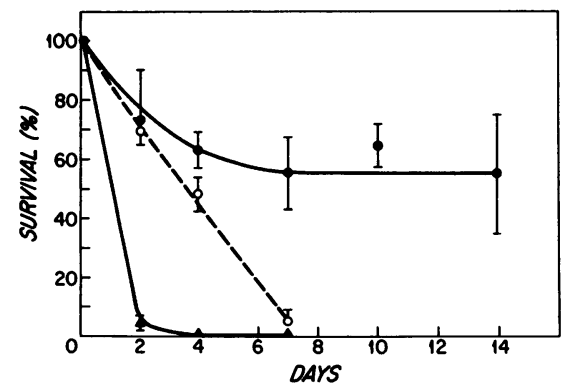

Figure 2. Survival of human eosinophils cultured in enriched medium alone $(\Delta)(n=4)$, in enriched medium containing IL-3 for only $2 \mathrm{~d}(0)(n=2)$, or in enriched medium containing IL-3 throughout the observation period $(\bullet)(n=8$ for cells cultured up to $7 \mathrm{~d}$ and $n$ $=3$ for cells cultured for 10 and $14 \mathrm{~d}$ ). The results are the mean \pm SD.
IL-3 containing medium, $55 \pm 12$ (mean \pm SD) and $53 \pm 21 \%$ (mean $\pm \mathrm{SD}$ ), respectively, of the starting eosinophils remained viable (Fig. 2). In contrast, no eosinophils survived to $4 \mathrm{~d}$ in enriched medium alone $(n=4)$, and only $5 \pm 4 \%$ (mean \pm range, $n=2$ ) survived to $7 \mathrm{~d}$ when exposed to IL-3 for only the first $48 \mathrm{~h}$ of the culture (Fig. 2). Fresh eosinophils (Fig. $3 A$ ) and IL-3 treated eosinophils (Fig. $3 B$ ) both contained eosin-staining granules and segmented nuclei as assessed by Wright's and Giemsa stains of cytocentrifuge preparations.

The effect of IL-3 on eosinophil viability appeared to be specific since neutrophils, the contaminating cell in the initial population of seeded leukocytes, were not present by day 2 of culture in $10 \mathrm{pM}$ IL-3. In a 3-d assay of other cytokines, IL-1 ${ }_{\alpha}$ $\left(10^{-3}-10^{2} \mathrm{U} / \mathrm{ml}\right)$, tumor necrosis factor $\left(10^{-1}-10^{5} \mathrm{U} / \mathrm{ml}\right), \mathrm{IL}-2$ $\left(1-10^{5} \mathrm{U} / \mathrm{ml}\right)$, IL-4 $\left(10^{-6}-10^{-2}\right.$ dilution), platelet-derived growth factor $\left(10^{-1}-10 \mathrm{U} / \mathrm{ml}\right)$, and basic fibroblast growth factor $\left(10^{-1}-10^{2} \mathrm{ng} / \mathrm{ml}\right)$ were each unable to maintain the viability of eosinophils above the baseline achieved in enriched medium alone.

In two experiments, eosinophils were cultured for $3 \mathrm{~d}$ in the presence of incremental concentrations of either IL-3 (0.01-100 pM) or GM-CSF (0.1-50 pM) alone and in combination with a fixed suboptimal concentration of the other cytokine, $1.0 \mathrm{pM}$ GM-CSF or $0.1 \mathrm{pM}$ IL-3. Culture of eosinophils in enriched medium containing both cytokines did not improve their viability compared with culture in medium containing either cytokine alone (Fig. 4). In two experiments, eosinophils cultured for $7 \mathrm{~d}$ in the presence of optimal concentrations of both 10 pM IL-3 and 10 pM GM-CSF, had a survival of $54 \pm 12 \%$ (mean \pm range, $n=2$ ) as compared with $49 \pm 2 \%$ for $10 \mathrm{pM} \mathrm{IL-3}$ alone.

Sedimentation density of eosinophils cultured in $I L-3$. The freshly isolated eosinophils that were cultured in $10 \mathrm{pM}$ IL-3 were routinely selected from the normodense fractions 5,6 , and 7 of the discontinuous metrizamide gradients. When the density of the cultured eosinophils was assessed after either 3 or $7 \mathrm{~d}$ of culture, $73 \pm 16$ and $93 \pm 5 \%$ (mean $\pm \mathrm{SD}, n=3$ ) of the eosinophils, respectively, were recovered in the hypodense gradient fractions 1,2 , and 3 . The results from a representative experiment are shown in Fig. 5.

IL-3 augmentation of calcium ionophore-induced generation of LTC 4 by eosinophils. When eosinophils were cultured in enriched medium supplemented with $10 \mathrm{pM} \mathrm{IL-3}$ for $7 \mathrm{~d}$, washed and activated with $2.5 \mu \mathrm{M}$ calcium ionophore in modified Tyrode's buffer, they generated approximately threefold more $\mathrm{LTC}_{4}(P<0.05)$ than freshly isolated cells (Table I).

The effect of exposure to enriched medium alone could only be assessed over a limited time interval because of a loss of viability. Whereas eosinophils preincubated for $60 \mathrm{~min}$ at $37^{\circ} \mathrm{C}$ in modified Tyrode's buffer generated $27 \pm 8 \mathrm{ng}$ of $\mathrm{LTC}_{4} / 10^{6}$ cells (mean $\pm \mathrm{SD}, n=3$ ), replicate eosinophils incubated in enriched medium generated $79 \pm 32$ ng upon activation with calcium ionophore. In order to further assess the ability of short-term exposure to IL-3 to also increase LTC $_{4}$ production, eosinophils were exposed to IL-3 in the presence of modified Tyrode's buffer. In two experiments in which eosinophils were incubated for $2,5,10,30,60$, and 90 min with 10 or 100 pM IL-3, a plateau for enhanced $\mathrm{LTC}_{4}$ generation occurred at $30 \mathrm{~min}$. Whereas preincubation in modified Tyrode's buffer alone did not increase $\mathrm{LTC}_{4}$ generation, there was a dose-dependent increase in the calcium ionophore-induced $\mathrm{LTC}_{4}$ generation from eosinophils that had been ex- 

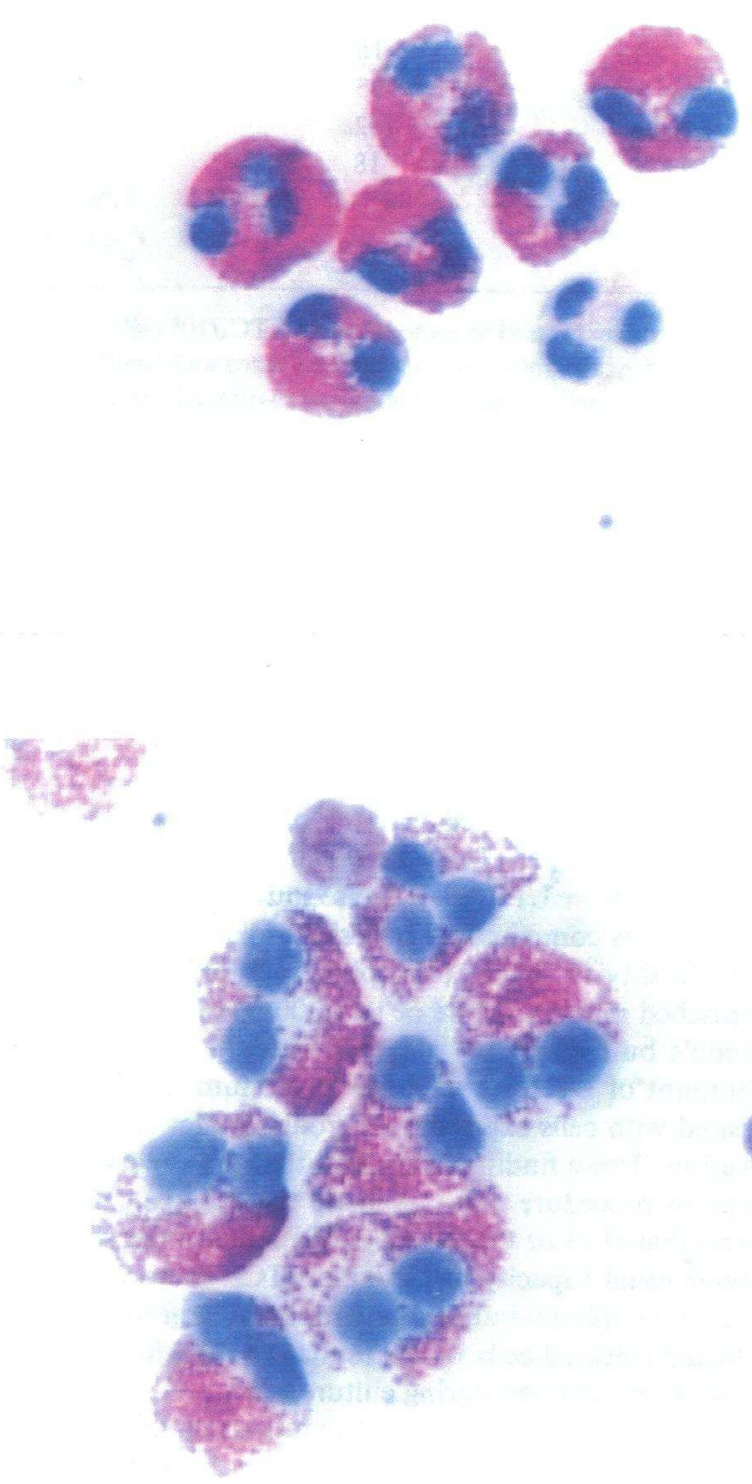

posed to increasing concentrations of IL-3 from 100 to 1,000 pM without a plateau (Fig. 6). Exposure of eosinophils to 100 and 1,000 pM IL-3 increased $\mathrm{LTC}_{4}$ generation from $22 \pm 4$ to $38 \pm 9$ and to $62 \pm 3 \mathrm{ng} / 10^{6}$ cells (mean $\pm \mathrm{SD}, n=3$ ), respectively $(P<0.01$ for both doses of IL-3).

IL-3 enhancement of eosinophil cytotoxicity against antibody-coated S. mansoni larvae. As shown in Fig. 7, when eosinophils were exposed to increments of IL-3, there was a dose-dependent increase in their cytotoxicity against antibody-coated $S$. mansoni larvae. Whereas freshly isolated eosinophils killed only $14 \pm 6 \%($ mean $\pm \mathrm{SD}, n=4)$ of these helminth targets, in the presence of $10 \mathrm{pM}$ or $100 \mathrm{pM} \mathrm{IL-3,}$ replicate eosinophils killed $42 \pm 22$ or $54 \pm 16 \%$ (mean \pm SD), respectively, of the targets $(P<0.05$ and $<0.02$, respectively). Eosinophils cultured for $7 \mathrm{~d}$ in the presence of concentrations of IL-3 and GM-CSF that were optimal for maintenance of
Figure 3. (A) Photomicrographs of cytocentrifuge preparations of Wright's and Giemsa stained freshly isolated eosinophils, and $(B)$ replicate eosinophils cultured in the presence of $10 \mathrm{pM}$ IL-3 for $14 \mathrm{~d}$. $1,200 \mathrm{X}$.

viability did not have enhanced cytotoxicity compared with replicate freshly isolated eosinophils (Table II). Eosinophils had enhanced cytotoxicity $(P<0.05)$ against the larvae, as compared with freshly isolated untreated eosinophils, only if they were cocultured with 3T3 fibroblasts in the presence of IL-3 or GM-CSF (Table II). When freshly isolated eosinophils were cocultured with $3 \mathrm{~T} 3$ fibroblasts for up to $2 \mathrm{~h}$ before their incubation with antibody-coated $S$. mansoni larvae there was no enhancement of eosinophil cytotoxicity. In other experiments, the addition of 48-h fibroblast-conditioned medium at a concentration of $1-25 \%$ had no effect on the killing assay.

\section{Discussion}

Human recombinant IL-3, like human recombinant GM-CSF (2), maintains the viability of human peripheral blood eosino- 

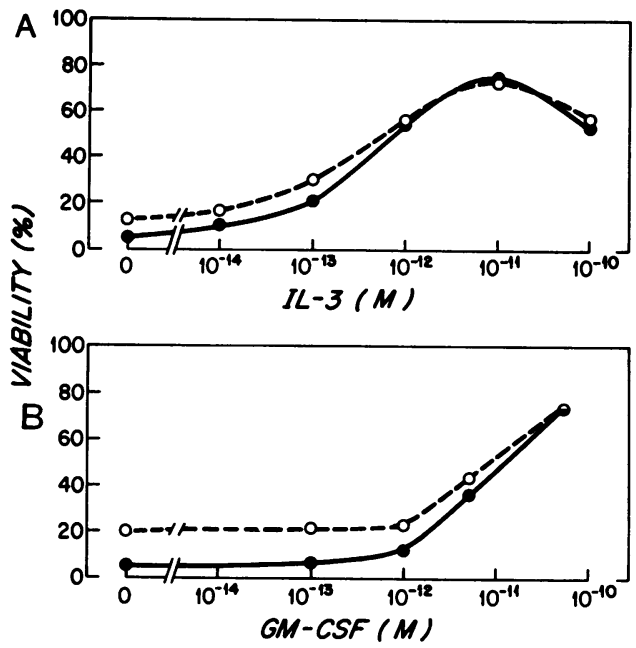

Figure 4. The effect of a fixed suboptimal concentration of $0.1 \mathrm{pM}$ IL-3 or $1.0 \mathrm{pM} \mathrm{GM-CSF}$ on the dose-dependent 3-d viability of eosinophils in response to the other cytokine. $(A)$ Eosinophils were cultured with incremental concentrations of IL-3 in the absence $(\bullet)$ or presence ( 0 ) of $1.0 \mathrm{pM}$ GM-CSF. (B) Eosinophils were cultured with incremental concentrations of GM-CSF in the absence $(\bullet)$ or presence (o) of $0.1 \mathrm{pM} \mathrm{IL-3}$. The results are the mean viability of two experiments done in duplicate.

phils for at least $14 \mathrm{~d}$ in vitro and enhances the functional properties of these cells. The viability of eosinophils after $3 \mathrm{~d}$ of culture was improved from a mean of $10 \%$ in enriched medium alone to a mean of $70 \%$ in the presence of $10 \mathrm{pM} \mathrm{IL-3}$ (Fig. 1). Eosinophils cultured for $3 \mathrm{~d}$ in the presence of various combinations of IL-3 and GM-CSF did not have an enhanced viability compared with an optimal concentration of either cytokine alone (Fig. 4). Under conditions in which the IL-3 supplemented enriched medium was replaced every $48 \mathrm{~h}$, eosinophil survival was constant by day 4 of culture, was a mean of $\sim 55 \%$ by day 7 , and was maintained for at least seven

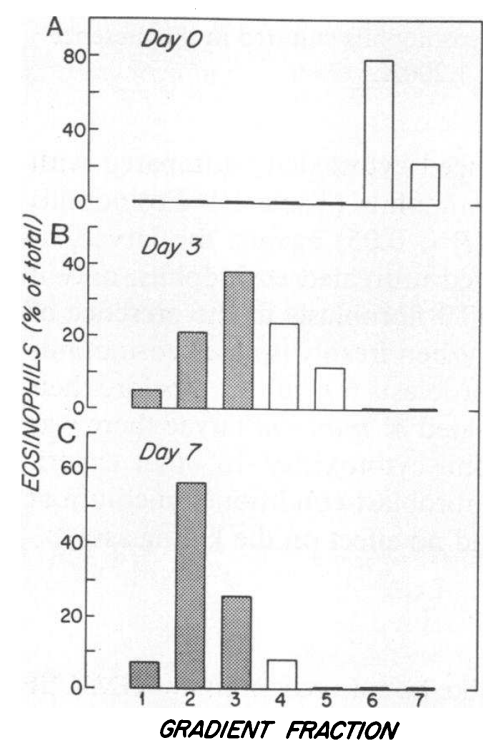

Figure 5. The density gradient distribution of $(A)$ freshly isolated eosinophils and eosinophils cultured in the presence of $10 \mathrm{pM} \mathrm{IL-3}$ for $(B) 3$ or $(C) 7 \mathrm{~d}$. Discontinuous metrizamide gradients fractions 1-6 refer to the eosinophils recovered at the $0 / 18,18 / 20$, $20 / 21,21 / 22,22 / 23$, and $23 / 24 \%$ interfaces, respectively; fraction 7 refers to the eosinophils in the cell pellet. The open bars and the stippled bars refer to eosinophils sedimenting in the normodense fractions $(5,6$, and 7$)$ and the hypodense fractions $(1,2$, and 3 ), respectively. The results are representative of three experiments for which the 7 -d survival was $56 \pm 3 \%$ (mean $\pm \mathrm{SD}$ ).
Table I. LTC 4 Generation by Calcium Ionophore-activated Eosinophils before and after $7 d$ of Culture in 10 pM IL-3

\begin{tabular}{ccc}
\hline Exp. & $\begin{array}{c}\text { Fresh } \\
\text { eosinophils }\end{array}$ & $\begin{array}{c}\text { Eosinophils } \\
\text { cultured in IL-3 }\end{array}$ \\
\hline 1 & 17 & 128 \\
2 & 18 & 132 \\
3 & 35 & 137 \\
4 & 102 & 115 \\
5 & 18 & 132 \\
Mean \pm SD & $38 \pm 36$ & $129 \pm 7$ \\
$P$ value* & & $P<0.05$
\end{tabular}

The data are expressed as nanograms of $\mathrm{LTC}_{4} / 10^{6}$ cells.

* The statistical significance between cultured and freshly isolated eosinophils was determined by the paired two-tailed $t$ test.

additional days (Fig. 2). The effect of IL-3 on eosinophils appeared to be cell specific since neutrophils, the contaminating cell in the initially seeded leukocytes, did not survive after $\mathbf{2 ~ d}$ of culture. Eosinophils cultured in various concentrations of IL- $1_{\alpha}$, IL-2, IL-4, tumor necrosis factor, basic fibroblast growth factor, or platelet-derived growth factor did not have prolonged viability, indicating that the effect of IL-3 and GMCSF on eosinophil viability was relatively cytokine specific.

Eosinophils cultured for $7 \mathrm{~d}$ in the presence of enriched medium supplemented with 10 pM IL-3, washed, and activated in modified Tyrode's buffer, generated approximately threefold more $\mathrm{LTC}_{4}$ in response to $2.5 \mu \mathrm{M}$ calcium ionophore A23187 as compared with freshly isolated eosinophils (Table I). Freshly isolated eosinophils, acutely exposed to either enriched medium alone or to 1,000 pM IL-3 in modified Tyrode's buffer (Fig. 6) also generated a threefold increased amount of $\mathrm{LTC}_{4}$ in response to calcium ionophore as compared with cells exposed to Tyrode's buffer alone before activation. These findings suggested that the isolation and purification procedure may attenuate the 5-lipoxygenase pathway and that IL-3 or GM-CSF $(2,19)$ induces the cells to restore their usual capacity to generate $\mathrm{LTC}_{4}$. Nevertheless, the calcium ionophore-induced generation of large amounts of $\mathrm{LTC}_{4}$ by the cultured cells indicates that this arachidonic acid pathway is maintained during culture.

The antibody-dependent cytotoxicity of freshly isolated eosinophils against $S$. mansoni larvae was increased threefold and fourfold in the presence of 10 and 100 pM IL-3, respectively (Fig. 7). Surprisingly, eosinophils cultured for $7 \mathrm{~d}$ in the

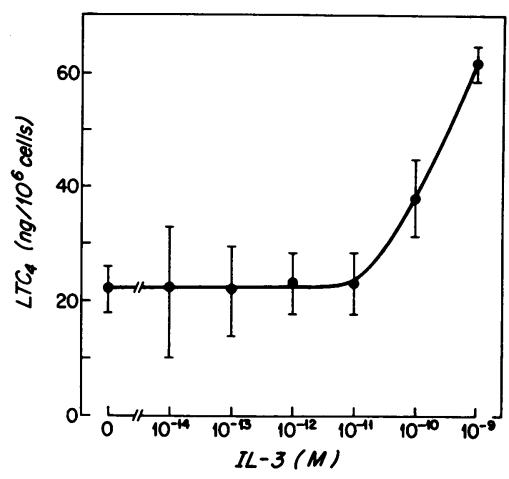

Figure 6. The acute effect of IL-3 on the dosedependent calcium ionophore A23187-induced generation of $\mathrm{LTC}_{4}$ by freshly isolated eosinophils. The results are expressed as the mean \pm SD for three experiments. As a positive control, replicate eosinophils acutely exposed to $10 \mathrm{pM}$ GM-CSF generated $56 \pm 23 \mathrm{ng}$ $\mathrm{LTC}_{4} / 10^{6}$ cells. 


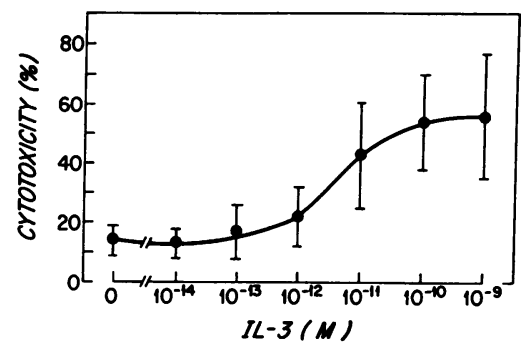

Figure 7. The IL-3 dependent augmentation of antibody-dependent cytotoxicity of freshly isolated eosinophils against $S$. mansoni larvae during a $24-\mathrm{h}$ incubation. The results are expressed as the mean \pm SD for four experiments. As a positive control, replicate eosinophils exposed to 10 pM GM-CSF killed $58 \pm 16 \%($ mean $\pm S D, n=3)$ of the antibodycoated larvae.

presence of either 10 pM IL-3 or 10 pM GM-CSF did not have enhanced cytotoxicity compared with replicate freshly isolated eosinophils (Table II) even though comparable cell preparations generated large amounts of $\mathrm{LTC}_{4}$ and were of the hypodense phenotype. Although we had observed that eosinophils cultured for $7 \mathrm{~d}$ in GM-CSF in the presence of 3T3 fibroblasts had enhanced cytotoxicity against antibody-coated $S$. mansoni larvae compared with freshly isolated cells, we had not studied the cytotoxicity of eosinophils maintained by GM-CSF in the absence of 3T3 fibroblasts (2). When eosinophils were cultured in enriched medium containing either 10 pM IL-3 or 10 pM GM-CSF and in the presence of 3T3 fibroblasts, they had enhanced cytotoxicity against antibody-coated $S$. mansoni larvae compared with freshly isolated eosinophils or eosinophils maintained by cytokines alone. Coculture of freshly isolated eosinophils with 3T3 fibroblasts for up to $2 \mathrm{~h}$ (or the addition of 3T3 conditioned medium to the killing assay) did not enhance eosinophil cytotoxicity. These findings suggested that there was no short-term direct effect of the $3 \mathrm{~T} 3$ fibroblasts on the cytotoxic potential of freshly isolated eosinophils. The long-term IL-3 independent effects of 3T3 fibroblasts on eo-

Table II. Cytotoxicity of Eosinophils against Antibody-coated $S$. mansoni Larvae before and after Culture

\begin{tabular}{|c|c|c|c|c|c|}
\hline \multirow[b]{3}{*}{ Exp. } & \multirow{3}{*}{$\begin{array}{c}\text { Fresh } \\
\text { eosinophils }\end{array}$} & \multicolumn{4}{|c|}{ Eosinophils cultured with* } \\
\hline & & \multicolumn{2}{|c|}{ IL-3 } & \multicolumn{2}{|c|}{ GM-CSF } \\
\hline & & $-3 \mathrm{~T} 3$ & $+3 \mathrm{~T} 3$ & $-3 \mathrm{~T} 3$ & $+3 \mathrm{~T} 3$ \\
\hline 1 & 11 & 3 & 20 & 5 & 42 \\
\hline 2 & 9 & 3 & 26 & 4 & 28 \\
\hline 3 & 9 & 21 & 40 & 17 & 41 \\
\hline 4 & 21 & 17 & 51 & 19 & 52 \\
\hline Mean \pm SD & $13 \pm 5$ & $11 \pm 8$ & $34 \pm 12$ & $11 \pm 7$ & $41 \pm 9$ \\
\hline$P$ value ${ }^{\ddagger}$ & & & $<0.05$ & & $<0.01$ \\
\hline
\end{tabular}

* Eosinophils, cultured for $7 \mathrm{~d}$ in the presence of $10 \mathrm{pM} \mathrm{IL-3}$ or 10 pM GM-CSF in the presence or absence of $3 \mathrm{~T} 3$ fibroblasts, were washed and assayed in enriched MEM alone. The data are expressed as percent of the larvae killed after $24 \mathrm{~h}$. Eosinophil survival for cells in culture for 7 days with IL-3 in the absence or presence of $3 \mathrm{~T} 3 \mathrm{fi}$ broblasts was $52 \pm 16$ (mean $\pm S D$ ) and $65 \pm 11 \%$, respectively. Eosinophil survival for cells in culture for $7 \mathrm{~d}$ with GM-CSF in the absence or presence of $3 \mathrm{~T} 3$ fibroblasts was $63 \pm 20$ and $77 \pm 13 \%$, respectively. ‡ The statistical significance of differences between sample means for each set of cultured eosinophils was based upon comparison to freshly isolated eosinophils as determined by the paired two-tailed $t$ test. sinophil cytotoxicity could not be assessed because 3T3 fibroblasts alone do not maintain the viability of eosinophils $(1,2)$. 3 T3 fibroblasts have been shown to regulate the viability and functional properties of rodent $(20,21)$ and human $(22)$ mast cells, and thus a connective tissue microenvironment appears to regulate certain properties of both eosinophils and mast cells.

During the first $7 \mathrm{~d}$ of culture in $10 \mathrm{pM}$ IL-3, eosinophils were progressively converted from normodense to hypodense (Fig. 5). Hypodense eosinophils have been found in the peripheral blood of patients with chronic helminthic infections (3), bronchial asthma $(5,23)$, atopy $(4)$, the idiopathic hypereosinophilic syndrome (3-6), and neoplasia (6). Hypodense eosinophils have enhanced antibody-mediated cytotoxicity (5), enhanced ligand-initiated chemotactic activity (24), enhanced ionophore-induced generation of $\mathrm{LTC}_{4}(7)$, increased consumption of oxygen and glucose (4-6), and enhanced expression of IgE low affinity receptors (25) compared with normodense eosinophils. The ability to convert normodense eosinophils into hypodense cells by culture with IL-3 suggests that IL-3 may be one of the cytokines that regulates the survival and phenotypic properties of eosinophils in these various disease states. That normodense eosinophils are converted into hypodense cells by culture in IL-3 or GM-CSF (2), or by coculture with human or bovine endothelial cells (1), suggests that the hypodense state may be the phenotype of mature eosinophils in inflamed tissue where they may be chronically exposed to cytokines produced by $\mathrm{T}$ cells or connective tissue cells. This possibility is supported by the finding of hypodense eosinophils in the pleural exudate of some patients with peripheral blood eosinophilia (4) and pulmonary infiltrative eosinophilia (6), even though the eosinophils present in their blood are predominantly normodense.

\section{Acknowledgments}

We thank Joel Pomerantz for excellent technical assistance, Dr. C. Sieff (Harvard Medical School) for his helpful discussions, and the Donsanto Corporation for the use of the color photomicroscopy equipment.

This work was supported by grants AI-22531, AI-23401, AI-23483, AM-35907, AR-38638, and HL-36110 from the National Institutes of Health (NIH), and in part by grants from the Robert Wood Johnson Foundation and the Hyde and Watson Foundation. M. Rothenberg is a predoctoral trainee supported in part by a Physician Scientist Training Program/Grant (AM-01401) from NIH. Dr. Stevens is an American Heart Association Established Investigator.

\section{References}

1. Rothenberg, M. E., W. F. Owen, Jr., D. S. Silberstein, R. J. Soberman, K. F. Austen, and R. L. Stevens. 1987. Eosinophils cocultured with endothelial cells have increased survival and functional properties. Science (Wash. DC). 237:645-647.

2. Owen, W. F. Jr., M. E. Rothenberg, D. S. Silberstein, J. C. Gasson, R. L. Stevens, K. F. Austen, and R. J. Soberman. 1987. Regulation of human eosinophil viability, density, and function by granulocyte/macrophage colony-stimulating factor in the presence of 3T3 fibroblasts. J. Exp. Med. 166:129-141.

3. DeSimone, C., G. Donell, D. Meli, F. Rosati, and F. Sorice. 1982. Human eosinophils and parasitic diseases. II. Characterization of two cell fractions isolated at different densities. Clin. Exp. Immunol. 48:249-255.

4. Winqvist, I., T. Olofsson, I. Olsson, A.-M. Persson, and T. Hall- 
berg, 1982. Altered density, metabolism and surface receptors of eosinophils in eosinophilia. Immunology. 47:531-539.

5. Prin, L., M. Capron, A.-B. Tonnel, O. Bletry, and A. Capron. 1983. Heterogeneity of human peripheral blood eosinophils: variability in cell density and cytotoxic ability in relation to the level and the origin of hypereosinophilia. Int. Arch. Allergy Appl. Immunol. 72:336-346.

6. Prin, L., J. Charon, M. Capron, P. Gosset, H. Taelman, A.-B. Tonnel, and A. Capron. 1984. Heterogeneity of human eosinophils. II. Variability of respiratory burst activity related to cell density. Clin. Exp. Immunol. 57:735-742.

7. Kajita, T., Y. Yui, H. Mita, N. Taniguchi, H. Saito, T. Mishima, and $T$. Shida. 1985. Release of leukotriene $\mathrm{C}_{4}$ from human eosinophils and its relation to the cell density. Int. Arch. Allergy Appl. Immunol. 78:406-410.

8. Metcalf, D. 1985 . The granulocyte-macrophage colony stimulating factors. Science (Wash. DC). 229:16-22.

9. Clark, S. C., and R. Kamen. 1987. The human hematopoietic colony-stimulating factors. Science (Wash. DC). 236:1229-1237.

10. Lopez, A. F., L. B. To, Y.-C. Yang, J. R. Gamble, M. F. Shannon, G. F. Burns, P. G. Dyson, C. A. Juttner, S. Clark, and M. A. Vadas. 1987. Stimulation of proliferation, differentiation, and function of human cells by primate interleukin 3. Proc. Natl. Acad. Sci. USA. 84:2761-2765.

11. Razin, E., J. N. Ihle, D. Seldin, J.-M. Mencia-Huerta, H. R. Katz, P. A. LeBlanc, A. Hein, J. P. Caulfield, K. F. Austen, and R. L. Stevens. 1984. Interleukin 3: a differentiation and growth factor for the mouse mast cell that contains chondroitin sulfate $\mathrm{E}$ proteoglycan. $J$. Immunol. 132:1479-1486.

12. Vadas, M. A., J. R. David, A. Butterworth, N. T. Pisani, and T. Siongok. 1979. A new method for the purification of human eosinophils and neutrophils and a comparison of the ability of these cells to damage schistosomula of Schistosoma mansoni. J. Immunol. 122:1228-1236.

13. Owen, W. F. Jr., R. J. Soberman, T. Yoshimoto, A. L. Sheffer, R. A. Lewis, and K. F. Austen. 1987. Synthesis and release of leukotriene $\mathrm{C}_{4}$ by human eosinophils. J. Immunol. 138:532-538.

14. Yang, Y.-C. A. B. Ciarletta, P. A. Temple, M. P. Chung, S. Kovacic, J. S. Witek-Giannotti, A. C. Leary, R. Kriz, R. E. Donahue, G. G. Wong, and S. C. Clark. 1986. Human IL-3 (multi-csf): identification by expression cloning of a novel hematopoietic growth factor related to murine IL-3. Cell. 47:3-10.

15. Gasson, J. C., R. H. Weisbart, S. E. Kaufman, S. C. Clark, R. M. Hewick, G. G. Wong, and D. W. Golde. 1984. Purified human granulocyte-macrophage colony-stimulating factor: direct action on neutrophils. Science (Wash. DC). 226:1339-1342.

16. Wong, G. G., J. S. Witek, P. A. Temple, K. M. Wilkins, A. C. Leary, D. P. Luxenberg, S. S. Jones, E. L. Brown, R. M. Kay, E. C. Orr, C. Shoemaker, D. W. Golde, R. J. Kaufman, R. M. Hewick, E. A. Wang, and S. C. Clark. 1985. Human GM-CSF: molecular cloning of the complementary DNA and purification of the natural and recombinant proteins. Science (Wash. DC). 228:810-815.

17. Levine, L., R. A. Morgan, R. A. Lewis, K. F. Austen, D. A. Clark, A. Marfat, and E. J. Corey. 1981. Radioimmunoassay of the leukotrienes of slow reacting substance of anaphylaxis. Proc. Natl. Acad. Sci. USA 78:7692-7696.

18. Dessein, A. J., A. E. Butterworth, M. A. Vadas, and J. R. David. 1983. Maturation in vivo of Schistosoma mansoni schistosomula after culture in vitro with granulocytes and antibody. Infect. Immun. 39:225-232.

19. Silberstein, D. S., W. F. Owen, J. C. Gasson, J. F. DiPersio, D. W. Golde, J. C. Bina, R. Soberman, K. F. Austen, and J. R. David. 1986. Enhancement of human eosinophil cytotoxicity and leukotriene synthesis by biosynthetic (recombinant) granulocyte-macrophage colony stimulating factor. J. Immunol. 137:3290-3294.

20. Levi-Schaffer, F., K. F. Austen, J. P. Caulfield, A. Hein, W. F. Bloes, and R. L. Stevens. 1985. Fibroblasts maintain the phenotype and viability of the rat heparin-containing mast cell in vitro. J. Immunol. 135:3454-3462.

21. Levi-Schaffer, F., K. F. Austen, P. M. Gravallese, and R. L. Stevens. 1986. Coculture of interleukin 3-dependent mouse mast cells with fibroblasts results in a phenotypic change of the mast cells. Proc. Natl. Acad. Sci. USA. 83:6485-6488.

22. Levi-Schaffer, F., K. F. Austen, J. P. Caulfield, A. Hein, P. M. Gravallese, and R. L. Stevens. 1987. Co-culture of human lung derived mast cells with mouse 3T3 fibroblasts: morphology and IgE-mediated release of histamine, prostaglandin $\mathrm{D}_{2}$, and leukotrienes. J. Immunol. 139:494-500.

23. Fukuda, T., S. L. Dunnette, C. E. Reed, S. J. Ackerman, M. S. Peters, and G. J. Gleich. 1985. Increased numbers of hypodense eosinophils in the blood of patients with bronchial asthma. Am. Rev. Respir. Dis. 132:981-985.

24. Wardlaw, A. J., R. Moqbel, O. Cromwell, and A. B. Kay. 1986. Platelet-activating factor: a potent chemotactic and chemokinetic factor for human eosinophils. J. Clin. Invest. 78:1701-1706.

25. Capron, M., H. L. Spiegelberg, L. Prin, H. Bennich, A. E. Butterworth, R. J. Pierce, M. Aliouaissi, and A. Capron. 1984. Role of IgE receptors in effector function of human eosinophils. J. Immunol. $132: 462-468$. 